\title{
Leukocytosis: Predictor of Radiological and Neurological Outcome of Patients of Traumatic Brain Injury Presented to Jinnah Hospital, Lahore (JHL)
}

\author{
SYED SHAHZAD HUSSAIN ${ }^{1}$, USMAN AHMAD KAMBOH ${ }^{1}$, ASIF RAZA ${ }^{1}$ \\ ABDUL HAFEEZ ${ }^{1}$, SAMAN SHAHID ${ }^{2}$, NAVEED ASHRAF ${ }^{1}$ \\ ${ }^{1}$ Department of Neurosurgery, Jinnah Hospital, Lahore, Pakistan \\ ${ }^{2}$ Department of Sciences \& Humanities, National University of Computer \& Emerging Sciences \\ (NUCES), Lahore Pakistan
}

DOI: https://doi.org/10.36552/pjns.v23i4.386

\begin{abstract}
Background/Objective: Catecholamines and cortisol cause raised TLC (total leukocyte count) and brain inflammation after injury. We found out that weather leukocytosis is predictive for radiological and neurological outcome in patientswith TBI presenting to JHL.
\end{abstract}

Materials and Methods: Blood samples of patients $(n=100)$ were collected on presentation in the emergency room, after 72 hours and on the $5^{\text {th }}$ day for TLC count.CT Brain was obtained on presentation in emergency, after 72 hours and on the $5^{\text {th }}$ day. The progression of imaging findings on CT scan were assessed and compared with TLC count. The outcome of these patients was assessed according to the Extended Glasgow Outcome Scale.

Results: TLC after TBI is raised initially and then it declined afterwards in mild and moderate TBI, but remained on the upper limit in moderate TBI. In severe TBI, TLC was raised initially and then it progressed to higher limits afterwards.These results showed that there is a strong relation between TLC and TBI.Regarding the association between radiological assessment and severity of injury along with raised TLC, it was observed that the patients having EDH had raised TLC along with expansion of hematoma, while patients with contusions, T-SAH (traumatic sub-dural hematoma) and SDH had TLC on upper limit, but there was no significant resolution of radiological severity.

Conclusion: WBC count can be used as a predictor of radiological outcome, as it was found that patients with severe head injury had raised TLC. TLC count can be used to assess the severity of injury and prognosis.

Keywords: Traumatic brain injury (TBI), Total leukocyte count (TLC), Extradural hematoma (EDH), Subdural hematoma (SDH), Traumatic subarachnoid hemorrhage (T-SAH), White blood cells (WBC), Glasgow outcome scale extended (GOSE).

\section{INTRODUCTION}

The association between the TBI (traumatic brain injury), TLC and progressive CT scan findings in relation with the outcome is still debatable. This current prospective study was conducted to find out that weather leukocytosis is predictive for radiological and neurological outcome in patients of TBI presenting to JHL.The burden of TBI was estimated to be 27.08 million in 2016, with incidence rates of 369 per $100,000 .{ }^{1}$ Studies from developed countries like US estimated the rate to be $400+$ per 100,000 . TBI, although on top for cause of deaths, ${ }^{2}$ is predicted to be the leading cause of casualties and hospital admission in developing and developed countries because of decrease rates of communicable disease in the future. The incidence is notably more in males ${ }^{3}$. An 
injury to the brain releases catecholamines inside the brain. ${ }^{4-6}$ Catecholamines in turn are responsible for an increase in circulating neutrophils by releasing them from the walls of the vessels. On the other hand, there is also a surge of cortisol, ${ }^{7-8}$ which inhibits the movement of leukocytes from vessels into the tissue and directly affect activation of leukocytes ${ }^{9-13}$, hence, causing raised TLC and brain inflammation after injury. CT scan imaging is an important modality and is most commonly used for radiological assessment of TBI. Progressive imaging findings can also help us regarding severity of injury in repeated CT scans. The association between the TBI, TLC and progressive CT scan findings in relation with the outcome is still debatable. The objective of the study was to look for the importance of TLC and CT scan findings in predicting outcome of TBI.

CT brain is the most common imaging modality used for the radiological assessment of severity of traumatic brain injury. CT brain plain is available round the clock in JHL for traumatic brain injury patients. The association between severity of TBI and the increased TLC count has been studied. But the relation between progressions of CT scan finding and variation of the TLC count along with the significant impact on the outcome is still debatable.

\section{MATERIALS AND METHODS}

\section{Study Design}

A prospective study was conducted at the Neurosurgery Department of JHL from January 2019 to July 2019.

\section{Inclusion Criteria}

100 patients who met inclusion criteria were included. Patients of both genders with an age range from 3-80 years were included with informed and written consent, who came to Emergency Department of JHL after traumatic brain injury after RTA and had CT Brain plain in an emergency along with the TLC count.

\section{Exclusion Criteria}

Patients with polytrauma, history of fall from height, penetrating brain injury and medical co-morbidities were excluded from the study. Those patients who had surgery were excluded. Patients who had depressed fractures were also excluded. Patients having more than one radiological findings (e.g., EDH and SDH) were excluded. Patients with severe traumatic brain injury usually develop pneumonia, UTI etc. We followed TLC and CT scan parameters on $5^{\text {th }}$ day and these patients usually develop infection by $5^{\text {th }}$ day. We excluded those patients of severe TBI from our study who developed early radiological signs of infection. Those patients who developed radiological signs of infection, e.g., X-ray findings or positive cultures were excluded from this study. The raised TLC on presentation and at 72 hours cannot be due to infection, because infective condition take few days to prevail. We also excluded all patients with co morbidities and surgery in order to minimize the cofounder of raised TLC by them.

\section{Data Collection}

Blood samples were collected on presentation in the emergency room, after 72 hours and on the $5^{\text {th }}$ day for TLC count.CT Brain was obtained on presentation in emergency, after 72 hours and on the $5^{\text {th }}$ day.The progression of imaging findings on CT scan were assessed and it was compared with TLC count. Patients were also divided into 3 categories according to severity of injury. The relation between severity of imaging, TLC count and CT scan finding was established to infer results. The outcome of these patients was assessed according to the Extended Glasgow Outcome Scale. Tabulation was done for the relationship between progression of radiological finding on CT scan with TLC and severity of injury. SPSS Version 24 was used for data analyses.

\section{RESULTS}

\section{Gender Distribution}

Out of 100 patients, 78 (78\%) were males and 22 (22\%) were females.

\section{Age Range}

It was observed that youngest patient was 3 years old and oldest was 80 years old. Out of total patients, $41 \%$ patients had age range from 21-40 years, as shown in the Table 1 .

Table 1: Age distribution.

\begin{tabular}{|c|c|c|}
\hline $\begin{array}{c}\text { Age Range } \\
\text { (Years) }\end{array}$ & $\begin{array}{c}\text { No of Patients } \\
(\mathbf{n}=\mathbf{1 0 0})\end{array}$ & $\begin{array}{c}\text { Percentage } \\
(\boldsymbol{\%})\end{array}$ \\
\hline $3-20$ & 22 & $22 \%$ \\
\hline
\end{tabular}




\begin{tabular}{|r|r|r|}
\hline $21-40$ & 41 & $41 \%$ \\
\hline $41-60$ & 28 & $28 \%$ \\
\hline $61-80$ & 9 & $9 \%$ \\
\hline
\end{tabular}

\section{Clinical Presentation and Management}

Out of 100 patients, $40 \%$ patients suffered from Moderate TBI, 37\% patients had Severe TBI and 23\% patients sustained Mild TBI, as shown in the Table 2.

Table 2: Distribution of head injury.

\begin{tabular}{|l|c|c|}
\hline Characteristics & $\begin{array}{c}\text { No of Patients } \\
(\mathbf{n = 1 0 0})\end{array}$ & $\begin{array}{c}\text { Percentage } \\
(\mathbf{\%})\end{array}$ \\
\hline Mild head injury & 23 & $23 \%$ \\
\hline Moderate head injury & 40 & $40 \%$ \\
\hline Severe head injury & 37 & $37 \%$ \\
\hline
\end{tabular}

It was observed that TLC count on the presentation was raised as compared to normal, but the TLC count variation among mild, moderate and severe TBI was not much significant, i.e. in mild head injury was $17.9 \times 10^{9} / \mathrm{L}$, in moderate $18.35 \times 10^{9} / \mathrm{L}$, and in severe $18.25 \times 10^{9} / \mathrm{L}$ (Table 3 ). On the other hand, TLC count on $5^{\text {th }}$ day was remarkably raised up to the range of $25.15 \times 10^{9} / \mathrm{L}$ in STBI which is much higher than TLC count on the $5^{\text {th }}$ day in mild and moderate head injury as shown in the Tables 3, 4 and 5 .

Table 3: Mild head injury.

\begin{tabular}{|l|l|l|}
\hline Time & Range & Mean Value \\
\hline On presentation & $9.7-26.1 \times 10^{9} / \mathrm{L}$ & $17.9 \times 10^{9} / \mathrm{L}$ \\
\hline After 72 hours & $7.8-28.6 \times 10^{9} / \mathrm{L}$ & $18.2 \times 10^{9} / \mathrm{L}$ \\
\hline On $5^{\text {th }}$ day & $3.8-14.0 \times 10^{9} / \mathrm{L}$ & $8.9 \times 10^{9} / \mathrm{L}$ \\
\hline
\end{tabular}

Table 4: Moderate head injury.

\begin{tabular}{|l|l|l|}
\hline Time & Range & Mean value \\
\hline On presentation & $6.7-30.0 \times 10^{9} / \mathrm{L}$ & $18.35 \times 10^{9} / \mathrm{L}$ \\
\hline After 72 hours & $4.6-21.7 \times 10^{9} / \mathrm{L}$ & $13.15 \times 10^{9} / \mathrm{L}$ \\
\hline On $5^{\text {th }}$ day & $3.0-23.2 \times 10^{9} / \mathrm{L}$ & $13.1 \times 10^{9} / \mathrm{L}$ \\
\hline
\end{tabular}

Table 5: Severe head injury.

\begin{tabular}{|l|l|l|}
\hline Time & Range & Mean value \\
\hline On presentation & $6.5-30.0 \times 10^{9} / \mathrm{L}$ & $18.25 \times 10^{9} / \mathrm{L}$ \\
\hline After 72 hours & $3.3-20.8 \times 10^{9} / \mathrm{L}$ & $12.05 \times 10^{9} / \mathrm{L}$ \\
\hline On $5^{\text {th }}$ day & $3.0-47.3 \times 10^{9} / \mathrm{L}$ & $25.15 \times 10^{9} / \mathrm{L}$ \\
\hline
\end{tabular}

Tabulation was done for progression of pattern of injury on CT scan and its relation with type of injury and TLC.21\% of total patients had EDH. The radiological progression for mild TBI with EDH at 72 hours was found to be $67 \%$ resolved, whereas at $5^{\text {th }}$ day, it was $33 \%$ resolved. For moderate TBI with $\mathrm{EDH}$, radiologicalprogression was found to be $25 \%$ resolved at 72 hours and $50 \%$ resolved at $5^{\text {th }}$ day. For severe TBI with EDH, it was $25 \%$ expanded at 72 hours and $62 \%$ expanded at $5^{\text {th }}$ day. The mean value of TLC for mild EDH was found to be $18.15 \times 10^{9} / \mathrm{L}$ at presentation, $12.75 \times 10^{9} / \mathrm{L}$ at 72 hours and $8.25 \times$ $10^{9} / \mathrm{L}$ at $5^{\text {th }}$ day. The mean value of TLC for moderate EDH was found to be $18.15 \times 10^{9} / \mathrm{L}$ at presentation, $14 \times 10^{9} / \mathrm{L}$ at 72 hours and $10.35 \times 10^{9} / \mathrm{L}$ at $5^{\text {th }}$ day. The mean value of TLC for severe EDH was found to be $13.15 \times 10^{9} / \mathrm{L}$ at presentation, $10.15 \times 10^{9} / \mathrm{L}$ at 72 hours and $25.15 \times 10^{9} / \mathrm{L}$ at $5^{\text {th }}$ day (Table 6 ).

\section{Operational Definitions for Radiological Parameters are as Follows:}

Radiological resolution will be considered significant clinically if volume reduced by $10 \mathrm{ml}$ for frontoparieto-occipital EDH and $5 \mathrm{ml}$ for temporal and posterior fossa EDH. Patients with SDH was observed $19 \%$. The radiologicalprogression for mild TBI with $\mathrm{SDH}$ at 72 hours and $5^{\text {th }}$ day was found to be $50 \%$ resolved. For moderate TBI with SDH, radiology was found to be $25 \%$ resolved at 72 hours and no further resolution was recorded at $5^{\text {th }}$ day. For severe TBI with $\mathrm{SDH}$, it was $7.6 \%$ expanded at 72 hours and no further resolution was recorded at $5^{\text {th }}$ day. The mean value of TLC for mild TBI with SDH was found to be $15.6 \times$ $10^{9} / \mathrm{L}$ at presentation, $20.3 \times 10^{9} / \mathrm{L}$ at 72 hours and $12.95 \times 10^{9} / \mathrm{L}$ at $5^{\text {th }}$ day. The mean value of TLC for moderate TBI with SDH was found to be $16.85 \times 10^{9} / \mathrm{L}$ at presentation, $9.3 \times 10^{9} / \mathrm{L}$ at 72 hours and $8.15 \times$ $10^{9} / \mathrm{L}$ at $5^{\text {th }}$ day. The mean value of TLC for severe TBI with SDH was found to be $19.5 \times 10^{9} / \mathrm{L}$ at presentation, $13 \times 10^{9} / \mathrm{L}$ at 72 hours and $13.6 \times 10^{9} / \mathrm{L}$ at $5^{\text {th }}$ day (Table 7). 
Table 6: $T L C$ count at different time intervals for EDH.

\begin{tabular}{|c|c|c|c|c|c|}
\hline & \multicolumn{3}{|c|}{ TLC Count on: } \\
\hline & & & Presentation & 72 Hours & $5^{\text {th }}$ Day \\
\hline \multirow{6}{*}{$\begin{array}{l}\text { EDH } \\
(21 \%)\end{array}$} & \multirow[b]{2}{*}{ Mild } & Radiology & -- & $67 \%$ resolved & $33 \%$ resolved \\
\hline & & TLC range (mean) & $\begin{array}{l}10.2-26.1 \times 10^{9} / \mathrm{L} \\
\left(18.15 \times 10^{9} / \mathrm{L}\right)\end{array}$ & $\begin{array}{l}8.6-16.9 \times 10^{9} / \mathrm{L} \\
\left(12.75 \times 10^{9} / \mathrm{L}\right)\end{array}$ & $\begin{array}{l}3.8-12.7 \times 10^{9} / \mathrm{L} \\
\left(8.25 \times 10^{9} / \mathrm{L}\right)\end{array}$ \\
\hline & \multirow[b]{2}{*}{ Moderate } & Radiology & -- & $25 \%$ resolved & $50 \%$ resolved \\
\hline & & TLC range (mean) & $\begin{array}{l}7.5-30.0 \times 10^{9} / \mathrm{L} \\
\left(18.75 \times 10^{9} / \mathrm{L}\right)\end{array}$ & $\begin{array}{l}9.4-18.6 \times 10^{9} / \mathrm{L} \\
\left(14 \times 10^{9} / \mathrm{L}\right)\end{array}$ & $\begin{array}{l}8.3-12.4 \times 10^{9} / \mathrm{L} \\
\left(10.35 \times 10^{9} / \mathrm{L}\right)\end{array}$ \\
\hline & \multirow[b]{2}{*}{ Severe } & Radiology & -- & $25 \%$ expanded & $62 \%$ expanded \\
\hline & & TLC range (mean) & $\begin{array}{l}6.5-19.8 \times 10^{9} / \mathrm{L} \\
\left(13.15 \times 10^{9} / \mathrm{L}\right)\end{array}$ & $\begin{array}{l}3.3-17.0 \times 10^{9} / \mathrm{L} \\
\left(10.15 \times 10^{9} / \mathrm{L}\right)\end{array}$ & $\begin{array}{l}3.0-47.3 \times 10^{9} / \mathrm{L} \\
\left(25.15 \times 10^{9} / \mathrm{L}\right)\end{array}$ \\
\hline
\end{tabular}

Table 7: TLC count at different intervals for SDH.

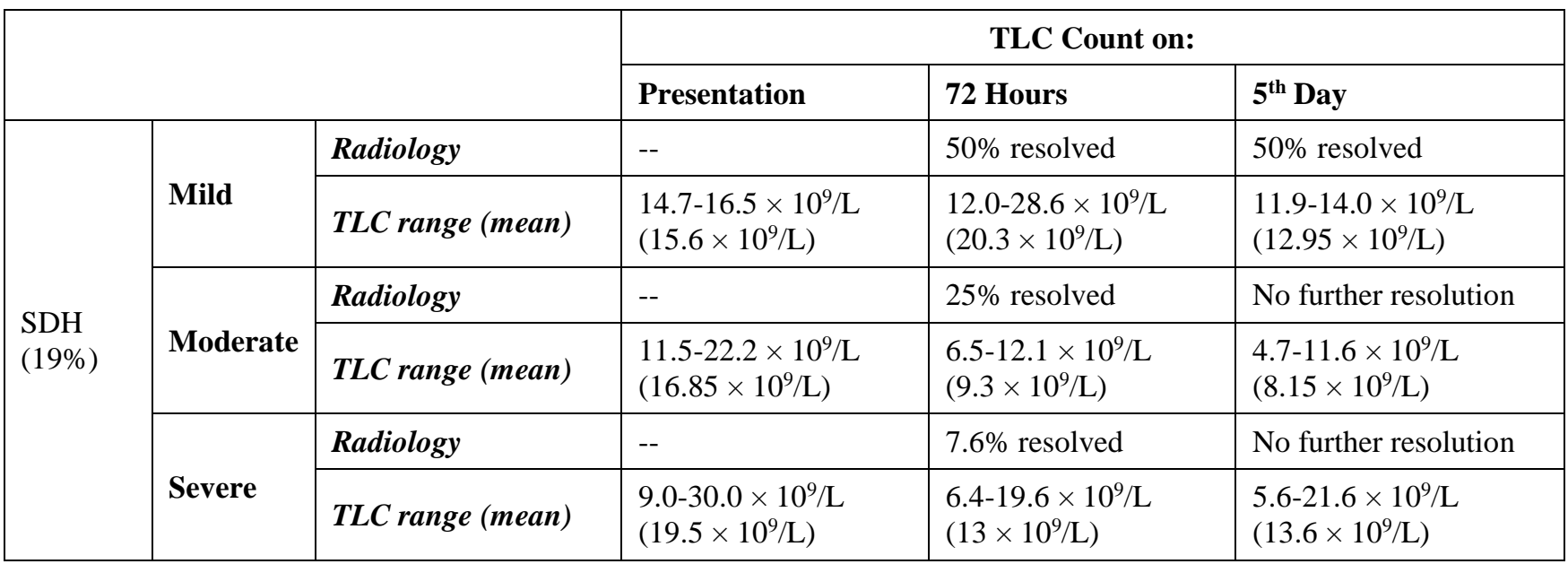

\section{Operational Definition for SDH Resolution.}

Radiological resolution will be considered significant clinically if midline shift reduced by $0.5 \mathrm{~cm} .39 \%$ patients were found to have brain contusions. The radiology for mild TBI with contusions at 72 hours was found to be $33.3 \%$ resolved, whereas, it was found to be $44.4 \%$ resolved at $5^{\text {th }}$ day. For moderate TBI with contusions, radiology was found to be $23 \%$ resolved at 72 hours and no further resolution was recorded at $5^{\text {th }}$ day. For severe TBI with contusions, no resolution was found at 72 hours and $5^{\text {th }}$ day. The mean value of TLC for mild TBI with contusions was found to be $17.45 \times 10^{9} / \mathrm{L}$ at presentation, $18.9 \times 10^{9} / \mathrm{L}$ at 72 hours and $11.5 \times 10^{9} / \mathrm{L}$ at $5^{\text {th }}$ day. The mean value of TLC for moderate TBI with contusions was found to be $16.8 \times 10^{9} / \mathrm{L}$ at presentation, $13.25 \times 10^{9} / \mathrm{L}$ at 72 hours and $13.15 \times 10^{9} / \mathrm{L}$ at $5^{\text {th }}$ day. The mean value of TLC for severe TBI with contusions was found to be $18 \times 10^{9} / \mathrm{L}$ at presentation, $12.6 \times 10^{9} / \mathrm{L}$ at 72 hours and $13.35 \times 10^{9} / \mathrm{L}$ at $5^{\text {th }}$ day (Table 8 ).

\section{Operational Definition for Radiological Resolution for Contusions:}

Radiological resolution will be considered significant clinically if the volume of contusion reduced by $5 \mathrm{ml}$. The radiological findings of T-SAH was observed in $9 \%$. The radiological progression for mild TBI with T-SAH at 72 hours and $5^{\text {th }}$ day was found to be $33.3 \%$ resolved. For moderate TBI with T-SAH, radiology was found to be $25 \%$ resolved at 72 hours and $50 \%$ resolved at $5^{\text {th }}$ day. For severe TBI with T-SAH, it was $7.6 \%$ expanded at 72 hours and no further resolution was recorded at $5^{\text {th }}$ day. The mean value of TLC for 
Table 8: $T L C$ count at different intervals for contusions.

\begin{tabular}{|c|c|c|c|c|c|}
\hline & & & \multicolumn{3}{|c|}{ TLC count on: } \\
\hline & & & Presentation & 72 Hours & $5^{\text {th }}$ Day \\
\hline \multirow{6}{*}{$\begin{array}{l}\text { Contusions } \\
(39 \%)\end{array}$} & \multirow[b]{2}{*}{ Mild } & Radiology & -- & $33.3 \%$ resolved & $44.4 \%$ resolved \\
\hline & & TLC range (mean) & $\begin{array}{l}9.7-25.2 \times 10^{9} / \mathrm{L} \\
\left(17.45 \times 10^{9} / \mathrm{L}\right)\end{array}$ & $\begin{array}{l}9.2-28.6 \times 10^{9} / \mathrm{L} \\
\left(18.9 \times 10^{9} / \mathrm{L}\right)\end{array}$ & $\begin{array}{l}9.0-14.0 \times 10^{9} / \mathrm{L} \\
\left(11.5 \times 10^{9} / \mathrm{L}\right)\end{array}$ \\
\hline & \multirow[b]{2}{*}{ Moderate } & Radiology & -- & $23 \%$ resolved & No further resolution \\
\hline & & TLC range (mean) & $\begin{array}{l}7.6-26.0 \times 10^{9} / \mathrm{L} \\
\left(16.8 \times 10^{9} / \mathrm{L}\right)\end{array}$ & $\begin{array}{l}4.8-21.7 \times 10^{9} / \mathrm{L} \\
\left(13.25 \times 10^{9} / \mathrm{L}\right)\end{array}$ & $\begin{array}{l}3.0-23.2 \times 10^{9} / \mathrm{L} \\
\left(13.15 \times 10^{9} / \mathrm{L}\right)\end{array}$ \\
\hline & \multirow[b]{2}{*}{ Severe } & Radiology & -- & No resolution & No resolution \\
\hline & & TLC range (mean) & $\begin{array}{l}7.9-28.1 \times 10^{9} / \mathrm{L} \\
\left(18 \times 10^{9} / \mathrm{L}\right)\end{array}$ & $\begin{array}{l}4.4-20.8 \times 10^{9} / \mathrm{L} \\
\left(12.6 \times 10^{9} / \mathrm{L}\right)\end{array}$ & $\begin{array}{l}5.8-20.9 \times 10^{9} / \mathrm{L} \\
\left(13.35 \times 10^{9} / \mathrm{L}\right)\end{array}$ \\
\hline
\end{tabular}

Table 9: $T L C$ count at different intervals for $T$-SAH.

\begin{tabular}{|c|c|c|c|c|c|}
\hline & \multicolumn{3}{|c|}{ TLC Count on: } \\
\hline & & & Presentation & 72 Hours & $5^{\text {th }}$ Day \\
\hline \multirow{6}{*}{$\begin{array}{l}\text { T-SAH } \\
(9 \%)\end{array}$} & \multirow[b]{2}{*}{ Mild } & Radiology & -- & $33.3 \%$ resolved & $33.3 \%$ resolved \\
\hline & & TLC range (mean) & $\begin{array}{l}12.0-21.9 \times 10^{9} / \mathrm{L} \\
\left(16.95 \times 10^{9} / \mathrm{L}\right)\end{array}$ & $\begin{array}{l}5.6-14.0 \times 10^{9} / \mathrm{L} \\
\left(9.8 \times 10^{9} / \mathrm{L}\right)\end{array}$ & $\begin{array}{l}8.9-10.0 \times 10^{9} / \mathrm{L} \\
\left(9.45 \times 10^{9} / \mathrm{L}\right)\end{array}$ \\
\hline & \multirow[b]{2}{*}{ Moderate } & Radiology & -- & $25 \%$ resolved & $50 \%$ resolved \\
\hline & & TLC range (mean) & $\begin{array}{l}10.1-17.0 \times 10^{9} / \mathrm{L} \\
\left(13.55 \times 10^{9} / \mathrm{L}\right)\end{array}$ & $\begin{array}{l}4.6-11.6 \times 10^{9} / \mathrm{L} \\
\left(8.1 \times 10^{9} / \mathrm{L}\right)\end{array}$ & $\begin{array}{l}6.0-16.2 \times 10^{9} / \mathrm{L} \\
\left(11.1 \times 10^{9} / \mathrm{L}\right)\end{array}$ \\
\hline & \multirow[b]{2}{*}{ Severe } & Radiology & -- & No resolution & No resolution \\
\hline & & TLC range (mean) & $\begin{array}{l}17.1-19.3 \times 10^{9} / \mathrm{L} \\
\left(18.2 \times 10^{9} / \mathrm{L}\right)\end{array}$ & $\begin{array}{l}9.7-11.6 \times 10^{9} / \mathrm{L} \\
\left(10.65 \times 10^{9} / \mathrm{L}\right)\end{array}$ & $\begin{array}{l}7.6-10.8 \times 10^{9} / \mathrm{L} \\
\left(9.2 \times 10^{9} / \mathrm{L}\right)\end{array}$ \\
\hline
\end{tabular}

Table 10: TLC count at different intervals for DAI.

\begin{tabular}{|l|l|l|l|l|l|}
\hline \multicolumn{2}{|c|}{} & \multicolumn{3}{c|}{ TLC count on: } \\
\cline { 4 - 6 } \multicolumn{2}{|c|}{} & Presentation & $\mathbf{7 2}$ Hours & $\mathbf{5}^{\text {th }}$ Day \\
\hline \multirow{3}{*}{$\begin{array}{l}\text { DAI } \\
(12 \%)\end{array}$} & $\begin{array}{l}\text { Mild } \\
(\mathbf{1 6 . 6 \% )}\end{array}$ & \multirow{2}{*}{ TLC range (mean) } & $\begin{array}{l}18.1-19.3 \times 10^{9} / \mathrm{L} \\
\left(18.7 \times 10^{9} / \mathrm{L}\right)\end{array}$ & $\begin{array}{l}10.6-12.0 \times 10^{9} / \mathrm{L} \\
\left(22.6 \times 10^{9} / \mathrm{L}\right)\end{array}$ & $\begin{array}{l}10.0-11.3 \times 10^{9} / \mathrm{L} \\
\left(10.65 \times 10^{9} / \mathrm{L}\right)\end{array}$ \\
\cline { 2 - 6 } & $\begin{array}{l}\text { Moderate } \\
(\mathbf{4 1 . 6 \% )}\end{array}$ & TLC range (mean) & $\begin{array}{l}9.3-14.8 \times 10^{9} / \mathrm{L} \\
\left(12.05 \times 10^{9} / \mathrm{L}\right)\end{array}$ & $\begin{array}{l}7.1-16.7 \times 10^{9} / \mathrm{L} \\
\left(11.9 \times 10^{9} / \mathrm{L}\right)\end{array}$ & $\begin{array}{l}6.8-11.0 \times 10^{9} / \mathrm{L} \\
\left(8.9 \times 10^{9} / \mathrm{L}\right)\end{array}$ \\
\cline { 2 - 6 } & $\begin{array}{l}\text { Severe } \\
(\mathbf{4 1 . 6 \% )}\end{array}$ & \multirow{2}{*}{ TLC range (mean) } & $\begin{array}{l}7.9-22.3 \times 10^{9} / \mathrm{L} \\
\left(15.1 \times 10^{9} / \mathrm{L}\right)\end{array}$ & $\begin{array}{l}8.0-16.8 \times 10^{9} / \mathrm{L} \\
\left(12.4 \times 10^{9} / \mathrm{L}\right)\end{array}$ & $\begin{array}{l}3.5-10.0 \times 10^{9} / \mathrm{L} \\
\left(6.75 \times 10^{9} / \mathrm{L}\right)\end{array}$ \\
\hline
\end{tabular}

mild TBI with T-SAH was found to be $16.95 \times 10^{9} / \mathrm{L}$ at presentation, $9.8 \times 10^{9} / \mathrm{L}$ at 72 hours and $9.45 \times$ $10^{9} / \mathrm{L}$ at $5^{\text {th }}$ day. The mean value of TLC for moderate
TBI with T-SAH was found to be $13.55 \times 10^{9} / \mathrm{L}$ at presentation, $8.1 \times 10^{9} / \mathrm{L}$ at 72 hours and $11.1 \times 10^{9} / \mathrm{L}$ at $5^{\text {th }}$ day. The mean value of TLC for severe TBI with 
T-SAH was found to be $18.2 \times 10^{9} / \mathrm{L}$ at presentation, $10.65 \times 10^{9} / \mathrm{L}$ at 72 hours and $9.2 \times 10^{9} / \mathrm{L}$ at $5^{\text {th }}$ day (Table 9).

\section{Operational Definition for Radiological Resolution for Traumatic Subarachnoid Hemorrhage:}

Radiological resolution will be considered significant if blood resolved.DAI was observed in $12 \%$. The mean value of TLC for mild DAI was found to be $18.7 \times$ $10^{9} / \mathrm{L}$ at presentation, $22.6 \times 10^{9} / \mathrm{L}$ at 72 hours and $10.65 \times 10^{9} / \mathrm{L}$ at $5^{\text {th }}$ day. The mean value of TLC for moderate DAI was found to be $12.05 \times 10^{9} / \mathrm{L}$ at presentation, $11.9 \times 10^{9} / \mathrm{L}$ at 72 hours and $8.9 \times 10^{9} / \mathrm{L}$ at $5^{\text {th }}$ day. The mean value of TLC for severe DAI was found to be $15.1 \times 10^{9} / \mathrm{L}$ at presentation, $12.4 \times 10^{9} / \mathrm{L}$ at 72 hours and $6.75 \times 10^{9} / \mathrm{L}$ at $5^{\text {th }}$ day (Table 10 ).

Out of 37 patients of severe head injury, GOS extended (Glasgow outcome scale) score of 16 patients was 1 , GOSE of 11 patients was 2 and GOSE score of 8 patients was 5 .In patients with moderate head injury, GOSE score of 31 patients was 8 and GOS extended score of 9 patients was 7 . In case of mild head injury GOSE (Glasgow outcome scale extended) score of all 23 patients was 8 at the time of discharge.

\section{DISCUSSION}

An injury to the brain causes release of catecholamines in the brain. Catecholamines and cortisol, which inhibit movement of leukocytes from vessels into the tissue and directly affect activation of leukocytes hence, causing raised TLC (total leukocyte count) and brain inflammation after injury. TBI is considered as a one of the common conditions leading to Grave outcomes.Assessment of TBI is routinely done with the help of GCS formulated by Teasdale and Jennett (1974). ${ }^{14}$ Hematological and radiological assessment also play a pivotal role in the management of TBI, but the correlation between TLC and severity of TBI is still debatable. ${ }^{15-17}$ There is a lack of evidence in quantification of CT scan findings for the assessment of severity TBI and TLC.Our study showed that TLC after TBI is raised initially and it declined afterwards in mild and moderate TBI, but remained on the upper limit in moderate TBI.In severe TBI, TLC was raised initially and it progressed to higher limits afterwards. These results showed that there is a strong relation between TLC and TBI. Regarding the association between radiological assessment and severity of injury along with raised TLC it was observed that patients having EDH had raised TLC along with expansion of hematoma while patients with contusions, T-SAH and SDH had TLC on upper limit but there was no significant resolution of radiological severity. Our findings are comparable with the Gurkanlar et al. ${ }^{18}$ representing a direct association between raised TLC and CT progression, but when we segregated the CT findings, it was observed that EDH patients had much significantly high TLC and expansion compared to brain contusions, T-SAH and SDH., ${ }^{79-20 .}$

\section{CONCLUSION}

WBC count can be predictor of radiological outcome as it was found that patients with severe head injury had raised TLC and there was significantly less resolution of CT scan findings in patients with raised TLC. Therefore, TLC count can be used to assess the severity of injury and prognosis.

\section{REFERENCES}

1. Global, regional, and national burden of traumatic brain injury and spinal cord injury, 1990-2016: a systematic analysis for the Global Burden of Disease Study, 2016.

2. Alhabdan S1, Zamakhshary M, Al-Naimi M, Al-Bedah K, Al-Enazi S, Al-Habib A. Epidemiology of traumatic head injury in children and adolescents in a major trauma center in Saudi Arabia implications for injury prevention. Ann Saudi Med. 2013; 33: 52-56.

3. Czigner A, Mihaly A, Farkas O, Büki A, Krisztin-Peva B, DoboE, Barzo P. Kinetics of the cellular immune response following closed head injury. Acta Neurochir (Wien). 2007; 149: 281-289.

4. Clifton GL, Ziegler MG, Grossman RG. Circulating catecholamines and sympathetic activity after head injury. Neurosurgery, 1981; 8: 10-14.

5. Hortangl H, Hammerle AF, Hackl JM, Brucke T, Rumpl E, Hortangl H: The activity of the sympathetic nervous system following severe head injury. Intensive Care Med. 1980; 6: 169-177.

6. Rosner MJ, Newsome HH, Becker DP. Mechanical brain injury: The sympathoadrenal response. J Neurosurg. 1984; 61: 76-86.

7. Boggs DR: The kinetics of neutrophilic leukocytes in health and in disease. Semins Hemat. 1967; 4: 359-386.

8. Dale DC. Leukocytosis, leukopenia, and eosinophilia. In: Harrison's, ed. Principles of Internal Medicine. New York: McGraw-Hill, Inc., 1991: 359-362.

9. Dietrich WD, Chatzipanteli K, Vitarbo E, Wada K, Kinoshita K. The role of inflammatory processes in the pathophysiology and treatment of brain and spinal cord trauma. Acta Neurochir Suppl. 2004; 89: 69-74. 
10. Fee D, Crumbaugh A, Jacques T, Herdrich B, Sewell D, Auerbach D, Piaskowski S, Hart MN, Sandor M, Fabry Z. Activated/effector CD4+ T cells exacerbate acute damage in the central nervous system following traumatic injury. J Neuroimmunol. 2003; 136: 54-66.

11. Gourin CG, Shackford SR.: Production of tumor necrosis factor-alpha and interleukin-l beta by human cerebral microvascular endothelium after percussive trauma. J Trauma. 1997; 42: 1101-1107.

12. Juurlink BH. Introduction: The role of inflammation in mediating damage following stroke and neurotrauma. Brain Pathol. 2000; 10: 93-94.

13. Lenzlinger PM, Hans VH, Joller-Jemelka HI, Trentz O, Morganti $\neg$ Kossmann MC, Kossmann T: Markers for cellmediated immune response are elevated in cerebrospinal fluid and serum after severe traumatic brain injury in humans. J Neurotrauma. 2001; 18: 47948930.

14. Teasdale G, Jennet B. Assessment of coma and impaired consciousness. Lancet. 1974; 2: 81-84.

15. Czigner A, Mihaly A, Farkas O, Büki A, Krisztin-Peva B, Dobo E, Barzo P. Kinetics of the cellular immune response following closed head injury. Acta Neurochir (Wien). 2007; 149: 281-289.

16. Keskil S, Baykaner MK, Ceviker N, Aykol Ş. Head Trauma and Leucocytosis. Acta Neurochir (Wien). 1994; 131: 211-214.

17. Rovlias A, Kotsou S. The Blood Leucocyte count and its prognostic significance in severe head injury. Surg Neurol. 1994; 55: 190-196.

18. Predictive Value of Leucocytosis in Head Trauma, Turkish Neurosurgery, 2009; 19 (3): 211-215.

19. Keskil S, Baykaner MK, Ceviker N, Aykol Ş. Head Trauma and Leucocytosis. Acta Neurochir (Wien). 1994; 131: 211-214.

20. Maas AIR, Hukkelhoven CWPM, Marshall LF, Steyerberg EW. Prediction of outcome in traumatic brain injury with computed tomographic characteristics: A comparison between the computed tomographic classification and combinations of computed tomographic predictors. Neurosurgery, 2005; 57 (6): 1173-1182.

\section{Additional Information}

Disclosures: Authors report no conflict of interest.

Ethical Review Board Approval: The study was conformed to the ethical review board requirements.

Human Subjects: Consent was obtained by all patients/participants in this study.

Conflicts of Interest:

In compliance with the ICMJE uniform disclosure form, all authors declare the following:

Financial Relationships: All authors have declared that they have no financial relationships at present or within the previous three years with any organizations that might have an interest in the submitted work.

Other Relationships: All authors have declared that there are no other relationships or activities that could appear to have influenced the submitted work.

Address for Correspondence: Dr. Syed Shahzad Hussain, Neurosurgery, Jinnah Hospital, Lahore, Email: drshahzadns@yahoo.com 


\begin{tabular}{|c|c|c|c|}
\hline \multicolumn{4}{|c|}{ AUTHORSHIP AND CONTRIBUTION DECLARATION } \\
\hline Sr.\# & Author's Full Name & Intellectual/Contribution to Paper in Terms of: & \multirow{4}{*}{$\begin{array}{l}\text { Signature by the } \\
\text { author(s) }\end{array}$} \\
\hline 1. & $\begin{array}{l}\text { Syed Shahzad Hussain } \\
\text { (Main/Principal Author). }\end{array}$ & $\begin{array}{l}\text { 1. Proposed Topics and Basic Study Design, } \\
\text { Methodology. }\end{array}$ & \\
\hline 2. & $\begin{array}{l}\text { Usman Ahmad Kamboh } \\
\text { (2nd Author) }\end{array}$ & \multirow{3}{*}{$\begin{array}{l}\text { 2. Data Collection and Calculations. } \\
\text { 3. Analysis of Data and Interpretation of Results } \\
\text { etc. } \\
\text { 4. Literature Review and Manuscript Writing. }\end{array}$} & \\
\hline 3. & $\begin{array}{l}\text { Asif Raza } \\
\text { (3rd Author) }\end{array}$ & & \\
\hline 4. & $\begin{array}{l}\text { Abdul Hafeez } \\
\text { (4th Author) }\end{array}$ & & \\
\hline 5. & $\begin{array}{l}\text { Saman Shahid } \\
\text { (5th Author) }\end{array}$ & \multirow[t]{2}{*}{ 5. Referencing and Proof reading } & \\
\hline 6. & $\begin{array}{l}\text { Naveed Ashraf } \\
\text { (6th Author) }\end{array}$ & & \\
\hline
\end{tabular}

Date of Submission: 09-09-2019

Date of Revision: 09-10-2019

Date of Online Publishing: 25-12-2019

Date of Print: 31-12-2019 